\title{
Pengaruh pembangunan infrastruktur transportasi terhadap minat kunjungan kembali wisatawan dan preferensi wisatawan di Kabupaten Lampung Selatan
}

\author{
Tezza Sorayaa $^{a},{ }^{*}$, Rahayu Sulistiyorini $^{\mathrm{b}}$, Citra Persadac \\ ${ }^{a}$ Mahasiswa Magister Teknik Sipil, Universitas Lampung, Jl. Soemantri Brojonegoro No. 1 Bandar Lampung, 35145, Indonesia \\ b Jurusan Teknik Sipil, Universitas Lampung, Jl. Soemantri Brojonegoro No. 1 Bandar Lampung, 35145, Indonesia \\ c Jurusan Teknik Sipil, Universitas Lampung, Jl. Soemantri Brojonegoro No. 1 Bandar Lampung, 35145, Indonesia
}

\section{H I G H L I G H T S}

- Infrastruktur transportasi yang berpengaruh adalah ketersediaan jalan tol, kualitas dermaga eksekutif dan akses ke bandara.

- Aksesibilitas berpengaruh sebesar $46,4 \%$ pada peningkatan kunjungan pariwisata di Lampung Selatan.

- Objek wisata alam merupakan prioritas wisatawan di Lampung Selatan.

\section{N F O A R T IK E L}

\section{Riwayat artikel:}

Diterima 14 Januari 2021

Diterima setelah diperbaiki 19 Maret 2021

Diterima untuk diterbitkan 25 Maret 2021

Tersedia secara online 1 April 2021

\section{Kata kunci:}

Aksesibiltas,

infrastruktur transportasi,

Kabupaten Lampung Selatan,

preferensi pariwisata.

\begin{abstract}
A B S T R A K
Tujuan penelitian adalah untuk mengetahui apakah dengan adanya jalan tol, dermaga eksekutif dan akses ke bandara yang semakin baik berpengaruh dalam meningkatkan jumlah wisatawan yang datang kembali. Untuk itu, tujuan penelitian ini adalah mengidentifikasi:karakteristik pasar wisatawan Kabupaten Lampung Selatan, preferensi wisatawan terhadap produk wisata di Kabupaten Lampung Selatan, dan pengaruh pembangunan infrastruktur trasnportasi terhadap kunjungan kembali wisatawan. Penelitian ini menggunakan kuisioner sebanyak 105 responden sedangkananalisis yang digunakan adalah analisis regresi linier berganda. Persamaan yang dihasilkan adalah $Y=$ $0,090+0,648 X_{1.1}+0,293 X_{2.2}$, dengan variabel $X_{1.1}$ adalah keterse-diaan jalan tol dan variabel $X_{2.2}$ adalah kualitas dermaga eksekutif. Hasil penelitian menunjukkan aksesibilitas memiliki pengaruh sebesar $46,4 \%$ terhadap peningkatan kunjungan kembali wisatawan, sedangkan $53,6 \%$ dipengaruhi oleh variabel lain yang tidak di masukan dalam model penelitian ini.Karakteristik wisatawan yang berkunjung di sekitar Lampung Selatan: berusia muda, berpenghasilan UMR dan kebanyakan wanita dengan tujuan untuk berlibur pada akhir pekan menggunakan mobil pribadi. Preferensi wisata lebih memilih wisata alam dan kuliner.Dari sisi sarana-prasarana, prioritas wisatawan adalah penyediaan air bersih, sedangkan kelancaran lalu lintas dankualitas jalan yang nyaman merupakan aksesibilitas yang diingikan wisatawan.
\end{abstract}

Diterbitkan oleh Jurusan Teknik Sipil Universitas Lampung

\section{Pendahuluan}

Perkembangan kegiatan wisata dalam sepuluh tahun terakhir ini mengalami peningkatan yang pesat. Hal ini didukung oleh semakin canggihnya teknologi dan mudahnya masyarakat mengakses internet, sehingga objek wisata yang terpencil akan dengan mudah terekspos di mediasosial sehingga menjadi destinasi yang paling dicari.Kegiatan berwisata bukanhanya kegiatan untuk melepaskan kepe-

\footnotetext{
* Penulis koresponden.

Alamate-mail: tesa.soray@gmail.com(T.Soraya).

Peer review dibawah tanggung-jawab Jurusan Teknik Sipil

Universitas Lampung.

https://doi.org/10.23960/rekrjits.v25i1.10
}

natan dan menghilangkan kejenuhan, namun saat ini berwisata sudah menjadi gaya hidup atau lifestyle.

Dalam RTRW Provinsi Lampung Tahun 2009-2029, rencana pengembangan kawasan pariwisata di Kabupaten Lampung Selatan [1], diantaranya wisata alam, yaitu pantai, pegunungan, minat khusus (paragliding dan gantole); wisata bahari, yaitu minat khusus di Pulau Sebesi dan Pulau Sebuku (selam, mancing, snorkeling); wisata budaya, yaitu wisata ziarah di makam Radin Intan II; dan wisata buatan yaitu wisata monumen di Menara Siger dan wisata resort di resort Kalianda

Posisi kepariwisataan Kabupaten Lampung Selatan berdasarkan kebijakan dan peraturan terkait pariwisata dalam tingkat nasional dan propinsi terdapat pada PP no. 
50 Tahun 2011 tentang Rencana Induk Pembangunan Kepariwisataan Nasional, bahwa Kabupaten Lampung Selatan ditetapkan sebagai kawasan strategis pariwisata nasional Krakatau dan sekitarnya, selain itu Peraturan Daerah Provinsi Lampung Nomor 6 tahun 2011 tentang Kepariwisataan pasal 12 dan 13, bahwa Kawasan Menara Siger dan kawasan cagar alam laut di sekitar Gunung Anak Krakatau Kabupaten Lampung Selatan merupakan kawasan strategis Propinsi Lampung untuk dikembangkan dan skema pengembangan jalur pariwisata salah satunya adalah koridor Menara Siger - Krakatau - Bandar Lampung - Teluk Kiluan [2].

Kabupaten Lampung Selatan memiliki banyak obyek wisata, diantaranya ada sepuluh objek wisata yang masuk dalam daftar prioritas, yaitu: Pantai Bagus, Pantai Merak Belantung, Pulau Sebesi, Pantai Minang Rua, Pantai Wartawan, Pemandian Way Belerang, Menara Siger, Kalianda Resort/Grand Elty, Alau-alau Boutique dan TPI Bom (kuliner).

Selanjutnya, ada tiga aspek yang harus dikembangkan dalam pariwisata yaitu aksesibilitas, atraksi dan amenitas (3A).Berdasarkan Peraturan Pemerintah No. 50 Tahun 2001, aksesibilitas pariwisata adalah semua jenis sarana dan prasarana transportasi yang mendukung pergerakan wisatawan dari wilayah asal wisatawan ke destinasi pariwisata maupun pergerakan di dalam wilayah destinasi pariwisata dalam kaitan dengan motivasi kunjungan wisata [3].Roger dan Slinn [4]menyatakan bahwa atraksi atau daya tarik adalah segala sesuatu yang terdapat di objek wisata yang menjadi daya tarik sehingga orang berkunjung ke tempat tersebut. Suwantoro [5] menegaskan bahwa atraksi dibagi ke dalam dua golongan, yaitu atraksi alam dan atraksi buatan manusia. Selanjutnya Suwantoro [5]juga menyatakan bahwa fasilitas pariwisata terdiri dari akomodasi, restauran, usaha rekreasi dan hiburan, transportasi serta sarana lain seperti souvenir shop, penyedia air dan sarana toilet.

Penelitian ini bertujuan untuk mengetahui pengaruh pembangunan infrastruktur transportasi sebagai salah satu aspek yang harus dikembangkan dalam pariwisata, terhadap kunjung-an kembali wisatawan. Untuk menganalisis keinginan kembali berkunjung juga diidentifikasi karakteristik pasar wisata Kabupaten Lampung Selatan dan preferensi wisatawan terhadap objek wisata di Lampung Selatan.

\section{Metode Penelitian}

Dalam penelitian ini, pengambilan sampel menggunakan purposive samplingdengan rumus slovindengan jumlah sebanyak 105 orang.Populasi dalam penelitian ini adalah wisatawan domestik yang berkunjung di dermaga eksekutif dan beberapa objek wisata di Kabupaten Lampung Selatan.

Jumlah variabel peneliian terdiri dari sembilan variabel yaitu(a) variabel Infrastruktur jalan tol $\left(X_{1}\right)$ dengan indikator ketersediaan jalan tol, kenyamanan jalan tol, akses dan konektivitas jalan tol,(b)variabel infrastruktur dermaga eksekutif $\left(X_{2}\right)$ dengan indikator ketersediaan dermaga eksekutif, kenyamanan dermaga eksekutif, akses dan konektivitas dermg eksekutif,(c) variabel infrastruktur Bandara Raden Inten II $\left(X_{3}\right)$ dengan ketersediaan bandara, kenyamanan bandara, akses dan konektivitas bandara,(d)variabel minat kunjungan ulang $(Y)$ dengan indikator pasti mengunjungi kembali suatu hari nanti dengan adanya infrastruktur transportasi
Teknik pengumpulan data dilakukan melalui survei.Indikator dari setiap variabel diperoleh melalui kuisioner sebagai instrumen penelitian.Transformasi data kualitatif menjadi kuantitatif dilakukan dengan skala likert yang terdiri dari sangat tidak setuju (STS), tidak setuju (TS), setuju (S) dan sangat setuju (SS).Sebelum digunakan, terlebih dahulu dilakukan uji reabilitas terhadap instrumen penelitian[6].

Selanjutnya, analisis data dilakukan dengan tiga jenis analisis yaitu: (a)analisis statistik kuantitatif (persentase), untuk mengetahui kecenderungan jawaban respoden dan fenomena di lapangan, (b) analisis tabulasi silang (crosstab) danuji chi-square untuk melihat keterkaitan/hubungan antara dua variabel dengan menggunakan chi-square dan koefisien kontigensi, sehingga dengan analisis ini dapat menggambarkan keterkaitan antar faktor berpengaruh dengan faktor terpengaruh. Variabel yang di analisis adalah variabel infrastruktur transportasi (jalan tol, dermaga eksekutif, dan bandara), karakteristik responden, karakteristik perjalanan responden terhadap minat kunjungan kembali responden, dan (c) analisis regresi linier berganda, yang digunakan untuk mengetahui pengaruh antara variabel independen dengan variabel dependen dalam bentuk Persamaan (1).

$$
Y=a+b_{1} X_{1}+b_{2} X_{2}+e
$$

dengan $Y$ adalah variabel terikat, $X_{1}$ adalah variabel bebas pertama, $X_{2}$ adalah variabel bebas kedua, a adalah nilai konstanta, $b_{1}$ adalah koefiien regresi untuk $X_{1}, b_{2}$ adalah koefisien regresi untuk $X_{2}$, dan e adalah standart error.

\section{Hasil dan Pembahasan}

\subsection{Hasil olah kuisioner}

Hasil olah kuisioner menunjukkan jumlah pengunjung terbesar berasal dari Propinsi Lampung sebesar 66\%, mayoritas berusia 17-25 tahun (78\%) dengan tingkat pendidikan terbesar yaitu SMA (52\%) dengan status pekerjaan sebagai pelajar/mahasiswa $(50 \%)$ sehingga tingkat penghasilan berada dibawah 2,5 juta/bulan dan pengunjung didominasi wanita (60\%). Untuk karakteristik perjalanan, tujuan perjalanan wisatawan untuk rekreasi/liburan sebesar $78 \%$, sedangkan untuk frekuensi kunjung-an baru pertama kali datang (50\%). Waktu kunjungan tertinggi adalah pada akhir pekan/weekend sebesar $47 \%$, dan aktivitas yang dihabiskan untuk berwisata yaitu selama 1 hari sebesar 55\%.Akomodasi terbesar adalah penginapan/homestay sebesar $37 \%$ dan biaya kunjungan maksimal 1 juta (54\%).Moda transportasi yang sering digunakan adalah moda darat sebesar 59\% dengan kendaraan yang dipakai mobil pribadi sebesar $47 \%$.

Daya tarik (atraksi) yang paling diminati adalah wisata alam (bahari, gunung, air terjun, goa), selain itu wisata kuliner juga bisa menambah daya tarik dengan mengembangkan makanan khas daerah.Fasilitas yang penting bagi wisatawan adalah penyediaan air bersih, adanya jaringan listrik, terjangkau oleh telekomunikasi.Kelancaran lalu lintas dan juga kualitas jalan yang baik menuju objek wisata juga berpengaruh dalam pengembang-an objek wisata. Dari segi promosi objek wisata, pengelola objek wisata atau pemerintah daerah berkerjasama dengan pihak ketiga seperti perusahaan, orgnisasi, komunitas dalam menciptakan suatu kegiatan/acara bulanan di objek wisata tersebut, sehingga saling mempromosikan produk masing-masing, 
sedangkan untuk informasi, pemerintah daerah bekerjasama dengan pengelola dermaga eksekutif, jalan tol, dan bandara agar memberikan informasi tentang objek wisata yang ada di Kabupaten Lampung Selatan, sehingga diharapkan orang-orang yang sedang berada di tempattempat tersebut menjadi tertarik dan ingin ber-kunjung. Partisipasi masyarakat sekitar objek wisata sangat berpengaruh. Masyarakat lokal sekitar objek diberdayakan sebagai tim pengelola dan terlibat dalam kegiatan berwisata, bisa sebagai guide, penjaga pantai, keamanan dan parkir, fotografer, pengelola warung makan/resto, pembuatan cenderamata, dengan pengelolaan yang baik tentunya mampu memberikan keuntungan pada masing-masing pihak sehingga tercipta suasana yang nyaman bagi pengunjung. Pantai Minang Rua dan Pulau Sebesi menjadi objek wisata prioritas.Menciptakan cenderamata atau souvenir khas daerah Kabupaten Lampung Selatan sehingga menjadi icon daerah.Membuat makanan khas yang terbuat dari laut, mengolahnya menjadi sesuatu yang unik yang hanya didapatkan di Kabupaten Lampung Selatan.

Ketersediaan infrastruktur transportasi tentunya mempermudah wisatawan dalam berkunjung ke suatu tempat wisata.Dari ketiga infrastruktur transportasi, ketersediaan dermaga eksekutif yang lebih mendukung peningkatan kegiatan wisata sebesar 34\%.Kesiapan dan kelayakan suatu infrastruktur berpengaruh meningkatkan jumlah penggunanya. Menurut wisatawan, dari ketiga infrastruktur tersebut, Dermaga Eksekutif yang dinilai paling siap dan layak digunakan dalam meningkatan kegiatan wisata sebesar 35\%, khususnya untuk pengunjung yang berasal dari Pulau Jawa. Berdasarkan akses dan konektifitas, ternyata Dermaga Eksekutif yang dinilai pengunjung sebagai infrastruktur yang mudah diakses/dijangkau dan terkoneksi dengan moda transportasi lainnya sebesar $35 \%$, setelah itu ada Bandara Raden Inten II juga terkoneksi dengan moda lainnya. Minat wisatawan untuk berkunjung kembali karena adanya pembangunan infrastruktur transportasi (jalan tol, dermaga eksekutif, bandara) di Lampung Selatan sangat tinggi yaitu sebesar $90 \%$ dari 105 kuisioner. Jadi pemerintah daerah Lampung Selatan sudah mempertimbangkan pariwisata sebagai sektor yang diunggulkan mengingat dengan adanya infrastruktur transportasi ini akan mempengaruhi minat kunjung wisatawan dari tahun ke tahun.

3.2 Hubungan variabel infrastruktur transportasi, karakteristik responden, karakteristik perjalanan dan minat kunjungan kembali wisatawan.

Tabel 1berikut ini menyajikan hubungan antar variabel berdasarkan nilai koefisien kontigensi.

Tabel 1.

Derajat hubungan antara variabel infrastruktur transportasi terhadap minat kunjung kembali berdasarkan koefisien kontigensi

\begin{tabular}{llll}
\hline $\begin{array}{l}\text { Variabel } \\
\text { infrastruktur } \\
\text { transportasi }\end{array}$ & $\begin{array}{l}\text { Minat } \\
\text { kunjung } \\
\text { kembali }\end{array}$ & $\begin{array}{l}\text { Koefisien } \\
\text { kontigensi }\end{array}$ & $\begin{array}{l}\text { Derajat } \\
\text { hubungan }\end{array}$ \\
\hline X1.1 & Y & 0,718 & Kuat \\
X1.2 & Y & 0,608 & Kuat \\
X1.3 & Y & 0,383 & Lemah \\
X2.1 & Y & 0,627 & Kuat \\
X2.2 & Y & 0,566 & Cukup \\
X2.3 & Y & 0,563 & Cukup \\
X3.1 & Y & 0,489 & Cukup \\
X3.2 & Y & 0,590 & Cukup \\
X3.3 & 0,491 & Cukup \\
\hline
\end{tabular}

Dari Tabel 1 diatas, variabel infrastruktur yang memiliki korelasi yang kuat dengan minat kunjung kembali $(Y)$ adalah ketersediaan jalan tol $\left(X_{1.1}\right)$, kualitas jalan tol $\left(X_{1.2}\right)$ dan ketersediaan dermaga eksekutif $\left(X_{2.1}\right)$. Hubungan yang terjadi antara variabel tersebut arahnya sama atau positif. Arah hubungan yang positif ini berarti bahwa tingginya ketersediaan jalan tol, kualitas jalan tol dan ketersediaan dermaga eksekutif diikuti dengan tingginya minat kunjung kembali wisatawan.

Dalam penelitian ini, karakteristik responden terdiri dari usia, jenis kelamin, asal, pendidikan terakhir, pekerjaan, dan penghasilan. Sedangkan berdasarkan hasil crosstab antara variabel karakteristik responden dengan variabel minat kunjungan kembali, maka diketahui bahwa tidak ada hubungan antara karakteristik responden dengan minat kunjung kembali wisatawan.Selanjutnya, Tabel 2 menyajikan variabel karakteristik perjalanan dengan minat kunjungan kembali.Karakteristik responden terdiri dari tujuan, frekuensi kunjungan, waktu kunjungan, lama kunjungan, akomodasi, biaya, moda transportasi, kendaraan.Hubungan yang terjadi antara variabel - variabel tersebut arahnya sama atau positif. Arah hubungan yang positif ini berarti bahwa tingginya lama kunjungan dan akomodasi diikuti dengan tingginya minat kunjungan kembali wisata-wan.

\section{Tabel 2}

Derajat hubungan karakteristik perjalanan dengan minat kunjung kembali wisatawan berdasarkan koefisien kontigensi

\begin{tabular}{llll}
\hline $\begin{array}{l}\text { Variabel } \\
\text { karakteristik } \\
\text { perjalnana }\end{array}$ & $\begin{array}{l}\text { Minat } \\
\text { kunjungan } \\
\text { kembali }\end{array}$ & $\begin{array}{l}\text { Koefisien } \\
\text { kontigensi }\end{array}$ & $\begin{array}{l}\text { Derajat } \\
\text { hubungan }\end{array}$ \\
\hline Lama Kunjungan & Y & 0,451 & Cukup \\
Akomodasi & Y & 0,446 & Cukup \\
\hline
\end{tabular}

\subsection{Pengaruh variabel infrastruktur transportasi terhadap minat kunjungan kembali wisatawan}

Analisa pengaruh antara infrastruktur transportasi yaitu jalan tol, dermaga eksekutif dan bandara Raden Inten II dengan minat kunjung kembali wisatawan menggunakan regresi berganda. Dari hasil analisa korelasi yang mempunyai derajat hubungan yang cukup dan lemah antar variabel bebas, maka didapatkan persamaan regresi berganda yang memiliki nilai koefisien determinasi paling tinggi seperti pada Persamaan (2).

$$
Y=0,090+0,648 X_{1.1}+0,293 X_{2.2}
$$

Dengan nilai $R^{2}$ adalah 0,464 , dimana $X_{1.1}$ adalah ketersediaan jalan tol dan $X_{2.2}$ adalah kualitas dermaga eksekutif.

Dari persamaan diatas, menunjukkan bahwa variabel dependen minat kunjung kembali wisatawan memiliki nilai konstan yaitu sebesar 0,090 dan koefisien variabel ketersediaan jalan tol sebesar 0,648 dan koefisien kualitas dermaga eksekutif sebesar 0,293 yang artinya kenaikan $1 \%$ dari ketersediaan jalan tol akan menambah nilai 0,648 ke minat kunjung kembali wisatawan dan kenaikan 1\% dari kualitas dermaga eksekutif juga menambah nilai 0,293 ke minat kunjung kembali wisatawan, dengan arah pegaruh sama - sama kearah positif. Nilai R square memiliki arti ketersediaan jalan tol dan kualitas dermaga eksekutif memberi pengaruh sebesar 0,464 terhadap minat kunjungan kembali. Hal ini berarti bahwa adanya 
pembangunan jalan tol dan peningkatan kualitas dari dermaga eksekutif hanya mempengaruhi peningkatan jumlah minat kunjungan kembali wisatawan di Lampung Selatan sebesar 46,4\%. Hal ini berarti ada variabel lain yang lebih besar pengaruhnya dalam meningkatkan kunjungan kembali wisatawan yaitu sebesar $53,6 \%$ yang tidak dimasukkan dalam model penelitian ini.

Hasil penelitian menunjukan bahwa variabel infrastruktur jalan tol dan kualitas dermaga eksekutif yang terdiri dari adanya pembangunan jalan tol dari bakauheni sampai ke Palembang dan kenyamanan dari dermaga eksekutif yang membawa wisatawan dari Pulau Jawa memiliki pengaruh terhadap minat kunjungan kembali wisatawan. Infrastruktur transportasi atau aksesibilitas yang terdiri dari kelancaran lalu lintas, kualitas jalan, biaya transportasi dan adanya angkutan umum berupa bus atau angkutan umum menuju objek wisata berpengaruh terhadap niat berkunjung kembali. Hasil ini sejalan dengan penelitian terdahulu yang dilakukan oleh Rezha[7], yang menyatakan bahwa aksesibilitas berpengaruh sigifikan terhadap keputusan wisatawan asing untuk berkunjung kembali.Nurhidayat [8]menyatakan aksesibilitas secara parsial berpengaruh signifikan terhadap niat berkunjung kembali ke Telaga Tambing.

Minat kunjung ulang wisatawan bukan saja dipengaruhi oleh aksesibilitas, namun juga dipengaruhi oleh atraksi dan amenitas, promosi dan kualitas pelayanan. Hal ini sesuai dengan RIPPARDA Provinsi Lampung tahun 2016, bahwa nilai estetika atau keindahan objek wisata menjadi penyebab $32,5 \%$ wisatawan untuk kembali berwisata di Lampung. Dari penelitian Damayanti dan Augusty [9]bahwa daya tarik wisata berpengaruh positif terhadap minat kunjung ulang.Sedangkan menurut Nuraeni [10], faktor yang mempengaruhi minat kunjung ulang adalah peningkatan promosi, peningkatan kualitas pelayanan, citra wisata yang didorong oleh peningkatan kualitas pelayanan dan daya tarik wisata yang didorong oleh peningkatan kualitas pelayanan.Diperkuat penelitian dari Marpaung [11] bahwa daya tarik wisata, kualitas pelayanan dan fasilitas wisata berpengaruh langsung dan signifikan baik terhadap kepuasan wisatawan maupun terhadap minat kunjungan ulang.

Dari hasil analisis kuisioner wisatawan, maka rekomendasi pembangunan objek wisata di Kabupaten Lampung Selatan adalah sebagai berikut. pengembangan objek wisata berorientasi alam berupa pantai, pulau, air terjun, gunung dan goa; mengembangkan makanan khas daerah sebagai daya tarik maupun ciri khas daerah Kabupaten Lampung Selatan; menyiapkan fasilitas yang nyaman dan lengkap berupa penyediaan air bersih, listrik, MCK, wifi dan spot foto yang menarik serta fasilitas yang ramah wanita; meningkatkan kualitas jalan/aksesibilitas langsung menuju objek - objek wisata alam dari pintu keluar tol, sehingga memudahkan wisatawan dalam berkunjung serta memfasilitasi angkutan lokal dari/ke objek wisata; bekerjasama dengan berbagai pihak ketiga dalam mempromosikan pariwisata di Lampung Selatan, seperti memasang baliho tentang objek wisata di pintu masuk ke Lampung Selatan dan simpul- simpul transportasi; melibatkan masyarakat sekitar objek wisata dalam menjaga dan mengembangkan pariwisata daerah; dan mengembangkan Pantai Minang Rua dan Pulau Sebesi sebagai objek wisata prioritas sehingga menjadi icon wisata Kabupaten Lampung Selatan.

\section{Simpulan}

1. Karakteristik wisatawan yang berkunjung adalah mayoritas wisatawan nusantara yang berasal dari dalam Provinsi Lampung serta provinsi tetangga yaitu Banten, Jawa Barat, DKI Jakarta dan Sumatera Selatan. Berdasarkan pendidikan dan pendapatan, umumnya lulusan SMA dan berpendapatan menengah ke bawah. Homestay dan rumah kerabat merupakan akomodasi yang dipilih sebagian besar wisatawan dengan lama tinggal hanya 1 hari. Moda transportasi yang digunakan adalah kendaraan pribadi dengan moda darat. Dari aspek preferensi, kebutuhan wisatawan dari sisi aksesibilitas adalah kelancaran jalur menuju ke objek wisata (tidak macet), jalan mulus, biaya murah dan ada angkutan umum(bus). Atraksi wisata yang menjadi pilihan wisatawan di Lampung Selatan adalah wisata alam, wosata kuliner dan wosata budaya. Sedangkan dari sisi amenitas, fasilitas yang dibutuhkan adalah ketersediaan air bersih, listrik, telekomunikasi, toilet yang bersih, rumah makan dan harga tiket ke obyek wisata yang terjangkau. Obyek wisata prioritas di Lampung Selatan, pertama yaitu wisata alam adalah Pantai Minang Rua dan Pulau Sebesi ( Kepulauan Anak Krakatau), kedua yaitu obyek wisata berupa resort dan buatan seperti Kalianda Resort, Pantai Merak Belantung dan Menara Siger.

2. Pengaruh infrastruktur transportasi terhadap minat kunjungan kembali wisatawan hanya $46,4 \%$, artinya pembangunan jalan tol dan dermaga eksekutif di Pelabuhan Bakauheni tidak berpengaruh besar terhadap minat kinjungan kembali wisatawan ke Lampubng Selatan. Hal ini menunjukkan bahwa aksesibilitas tidak cukup kuat meningkatkan kunjungan wisatawan ke Kabupaten Lampung Selatan. Ada factor lainnya, sebesar 53,6\% yang mempengaruhi kunjungan wisatawan ke Kabupatenb Lampung selatan seperti atraksi dan amenitas.

3. Dari karakteristik dan preferensi wisatawan yang datang ke Lampung Selatan, maka Pemerintah Kabupaten Lampung Selatan hendaknya meningkatkan kualitas produk wisata berupa atraksi dan amenitas yang meliputi pengembangan obyek wisata alam dan resort berbasis alam ( Pantai Minang Rua dan Pulau Sebesi), mengembangkan makanan khas daerah, memperbaiki ketersediaan sarana air bersih, listrik, telekomunikasi (wifi) dan fasilitas umum di obyek wisata (toilet, tong sampah, dan spot foto) yang mudah diakses untuk anak-anak, orang tua dan perempuan. Wisatawan berharap peningkatan kualitas jalan dan transportasi berupa angkutan umum ke obyek wisata, selanjutnya perlu melibatkan masyarakat dalam pengembangan obyek wisata dan bekerja sama dengan berbagai pihak untu promosi.

\section{Daftar Pustaka}

[1] Lembaga Penelitian dan Pengabdian Kepada Masyarakat Universitas Lampung: Review Ripparda Provinsi Lampung 2010-2025, Dinas Pariwisata dan Ekonomi Kreatif Propinsi Lampung 2016

[2] Badan Perencanaan Pembangunan Daerah Propinsi Lampung. Rencana Tata Ruang Wilayah Provinsi Lampung Tahun 2009-2029. 2009.

[3] Republik Indonesia. Peraturan Pemerintah Republik Indonesia Nomor 50 Tahun 2011 tentang Rencana Induk 
Pembangunan Kepariwisataan Nasional Tahun 2010 - 2025.

Dinas Pariwisata dan Ekonomi Kreatif Provinsi Lampung dan Lembaga Penelitian Dan Pengabdian Kepada Masyarakat Universitas Lampung. 2016.

[4] Roger, A., Slinn, J:: Tourism management of facilities. London, Pitman Publishing, 1998

[5] Suwantoro, G.:Dasar-dasar pariwisata. Penerbit Andi, Yogyakarta, 2000

[6] Sugiyono.Metode penelitian kuantitatif kualitatif. Penerbit Alfabeta, Bandung, 2012

[7] Rheza, S.A., Pengaruh daya tarik, fasilitas dan aksesibilitas terhadap keputusan wisatawan asing berkunjung kembali ke Aloita Resort di Kabupaten Kepulauan Mentawai. Jurnal Pelangi, 7, 1,STKIP PGRI, Sumatera Barat, 2015

[8] Hidayat, T.T.N.: Pengaruh aksesibilitas dan citra destinasi terhadap niat berkunjung kembali ke Telaga Tambing. Jurnal Ilmu Manajemen Universitas Tadulako,3, 2, Mei 2017, 201212

[9] Damayanti, M., Augusty, T.F.: Analisis faktor - faktor yang mempengaruhi minat kunjung ulang pada objek wisata pemandian air panas Guci di KabupatenTegal. Diponegoro Journal Of Management, 4, 4, 2015, 1-15

[10] Nuraeni, B.S.: Analisis faktor-faktor yang mempengaruhi minat kunjung ulang wisatawan museum Ranggawarsita Semarang. Jurnal Bisnis Strategi,23,1, Juli2014, 1-20

[11] Marpaung, B.: Pengaruh daya tarik, kualitas pelayanan, fasilitas dan keselamatan dengan kepuasan wisatawan sebagai variabel intervensiterhadap minat kunjungan ulang wisatawan. Jurnal Penelitian Manajemen, 1, 2, Oktober 2019, 144-156 